\title{
PERAN KOMUNITAS BERBAGI NASI DALAM MEMBANTU PEMERINTAH UNTUK MENSEJAHTERAKAN KAUM DHUAFA
}

(studi pada Komunitas Berbagi Nasi Kabupaten Tulungagung)

\author{
Erma Try Armylasari \\ Universitas Islam Balitar \\ Email : erma.try@yahoo.com \\ Ferida Asih Wiludjeng \\ Program Studi Ilmu Administrasi Negara, Universitas Islam Balitar \\ e-mail: wiludjeng02@gmail.com
}

\begin{abstract}
ABSTRAK
Penelitian ini dilatarbelakangi oleh tingginya tingkat kemiskinan di Indonesia yang juga mengakibatkan tingkat pengangguran yang tinggi. Pengangguran merupakan salah satu masalah yang seringkali muncul dalam proses pembangunan. Meningkatkan pengangguran bisa menjadi penghambat bagi jalannya pembangunan dan berpotensi menimbulkan masalah-masalah dalam bidang sosial maupun ekonomi. Pertumbuhan penduduk yang tinggi, kinerja perekonomian, serta peran pemerintah terutama dalam kebijakan upah minimum juga, juga menjadi salah satu faktor yang berpengaruh terhadap pengangguran. Pengangguran disebabkan karena kurangnya lapangan pekerjaan yang tersedia dan kurangnya kemauan masyarakat Indonesia untuk membuka lapangan kerja sebagai wirausaha. Jumlah lapangan kerja yang saat ini tersedia tidak seimbang dengan jumlah usia produktif di Indonesia. Hal tersebutlah membuat sebagian besar masyarakat Indonesia tidak memiliki pekerjaan. Kemiskinan adalah salah satu masalah dalam perekonomian Indonesia yang kompleks dan mendasar. Perlu dicari solusi untuk mengatasi atau paling tidak mengurangi tingkat kemiskinan. Kemiskinan telah menjadi salah satu permasalahan yang banyak dialami dan menjadi perhatian oleh negara-negara di dunia baik negara maju maupun negara berkembang. Munculnya persoalan kemiskinan ini tidak dapat dilepaskan dari pandangan negara-negara yang hirau akan pentingnya perlindungan terhadap individu, tanpa memandang status kewarganegaraan, suku, ras dan agama. Banyak sekali penyebab sehingga banyak negara yang memiliki permasalahan tersebut. Salah satu negara yang mengalami maalah ini adalah Indonesia. Salah satu penyebab terjadi kemiskinan adalah karena tingkat pengangguran yang tinggi. Pengangguran dan kemiskinan memiliki hubungan yang erat. Karena tingkat pengangguran dan kemiskinan yang tinggi di Indonesia tersebut menggerakkan hati nurani masyarakat yang lebih mampu untuk membantu kaum dhuafa. Kemudian masyarakat yang lebih mampu mendirikan komunitas sosial yang dinamakan Komunitas Berbagi Nasi.
\end{abstract}

Kata kunci : kemiskinan, Komunitas Berbagi Nasi, pengangguran

ABSTRACT

This research [of] background by height mount poorness in Indonesia which also result high unemployment storey;level. Unemployment is one of the problem which often appear with developing process and potentially causing social and economy problem. Growth in population, economic performance, and government 
role especially in minimum wage policy becomes of the factor to effect on unemployment. Unemployment caused by the lack of available work field and lack of willingness of Indonesia society to open employment as wirausaha. Amount of employment which is available in this time incommensurate to amount of productive age in Indonesia. The matter make most Indonesia society [do] not have work. Poorness is one of the problems in the Indonesian economy complex and fundamental. Need to find solutions to overcome reduce the poorness level. Poorness has become one of the many problems experienced and to be concerned by countries in the world, both development and state developing. The emergence of this problem of poorness can not be separated from view nations that care about the importance of protecting indiviuals, no longer view the status of citizenship, ethnic, race, and religion. There are so many cause until that many countries have such problems. One of problems poorness happen because high rate of unemployment . unemployment and poorness have a tight relationship. Because of mount the high poorness and unemployment in Indonesia excite society nurani which better able to assist clan of dhuafa. Later; Then more society can found social community which named Komunitas Berbagi Nasi.

Key words : poorness, Komunitas Berbagi Nasi, unemployment

\section{PENDAHULUAN}

Negara berkembang adalah istilah yang digunakan untuk menyebut negara yang memiki tingkat kesejahteraan pada warganya yang rendah. Dalam hal ini yang diukur akan kesejahteraan adalah kekayaan yang dimili oleh warga negara. Negara berkembang memiliki tingkat kekayaan yang rendah. Hal ini terjadi karena disebagian besar negara berkembang mengalami kemiskinan dan pengangguran yang tinggi. Sebab sebuah negara dikatakan masuk dalam kategori negara berkembang adalah karena tingkat pertumbuhan penduduk sangat tinggi dan tidak seimbang dengan tingkat produktivitas nya yang rendah sehingga mengalami pengangguran yang tinggi. Hal itu terjadi diIndonesia sehingga hal ini menjadikan Indonesia masuk menjadi salah satu negara berkembang.

Kemiskinan adalah keadaan dimana terjadi ketidakmampuan untuk memenuhi kebutuhan dasar seperti sandang, pangan, papan, kesehatan dan pendidikan. Kemiskinan dapat disebabkan oleh langkanya bahan pemenuh kebutuhan dasar ataupun kurangnya pendidikan dan pekerjaan. Kebanyakan negara berkembang dilanda permasalahan kemiskinan ini. Dan kemiskinan adalah penyakit yang sulit untuk diberantas atau disembuhkan. Masih belum ada cara jitu yang tercipta untuk mengeluarkan warga negara agar dapat keluar dari lubang kemiskinan.

Menurut James C. Scott dikutip dalam tulisan Gregorius Sahdan dalam mengatakan bahwa; dalam negara yang salah urus, tidak ada persoalan yang lebih 
besar selain persoalan kemiskinan. Kemiskinan telah membuat jutaan anak-anak tidak bisa mengenyam pendidikan yang berkualitas, kesulitan membiayai kesehatan, kurangnya tabungan dan tidak adanya investasi, kurangnya akses ke pelayanan public, kurangnya lapangan pekerjaan, kurangnya jaminan sosial dan perlindungan terhadap keluarga, menguatnya arus urbanisasi kekota, dan yang lebih parahnya kemiskinan menyebabkan jutaan rakyat memenuhi kebutuhan pangan, sandang, dan papan secara terbatas. Kemiskinan menyebabkan masyarakat Desa rela mengorbankan apa saja demi keselamatan hidup, safety life (James C. Scott,1981)

Sebagai salah satu negara berkembang, kemiskinan di Indonesia menunjukan angka yang memprihatinkan dari tahun ke tahun seperti sebuah aksi gali lobang tutup lobang yang tak bisa tamat. Bahkan kemiskinan ini merupakan persoalan yang seperti tidak mau beranjak dari Indonesia. Dan kemiskinan ini merupakan persoalan yang sangat gawat yang menentukan pergerakan sebuah negara mampu atau tidaknya berada dalam keadaan yang lebih baik. Pemerintah Indonesia sudah mengeluarkan berbagai cara untuk bisa mengeluarkan masyarakatnya dari belenggu kemiskinan. Namun kenyataannya berbagai program dari pemerintah belum mampu menyentuh pokok yang menimbulkan masalah kemiskinan ini. Salah satu program pemerintah untuk membantu masyarakat miskin adalah program Bantuan Langsung Tunai yang merupakan kompensasi yang diberikan usai penghapusan subsidi minyak tanah dan program konversi bahan bakar gas. Bantuan lainnya yang diupayakan oleh pemerintah Indonesia seperti contoh dalam bidang kesehatan yaitu pemerintah memberikan jaminan kesehatan untuk masyarakat miskin. Namun hal tersebut tidak memiliki dampak signifikan terhadap pengurangan angka kemiskinan. Banyak warga miskin yang terhambat membuat kartu untuk jaminan kesehatan ini.Beberapa pakar mengatakan bahwa hal-halyang diberikan oleh pemerintah Indonesia tersebut sudah seharusnya dilakukan pemerintah. Baik ada atau tidaknya masalah kemiskinan disebuah negara. Negara memang wajib menyediakan jaminan kesehatan dan menjamin kesejahteraan masyarakatnya seperti yang tercantum didalam UUD 1945.

Permasalahan dalam pemerintah selain dalam hal kemiskinan yaitu adalah masalah pengangguran. Pengangguran adalah istilah untuk orang yang tidak bekerja sama sekali, sedang mencari kerja, kerja kurang dari dua hari selama seminggu atau seseorang yang sedang berusaha mendapat pekerjaan. Pengangguran pada umumnya disebabkan karena jumlah angkatan kerja tidak sebanding dengan jumlah lapangan 
kerja yang mampu menampungnya. Banyak sekali penduduk Indonesia yang lebih memilih untuk menanti lowongan pekerjaan daripada membuka lowongan pekerjaan.

Pemerintah Indonesia dalam mengatasi masalah pengangguran ini telah melakukan berbagai upaya dengan mengeluarkan berbagai kebijakan yang akan meminimalisir akan terjadinya pengangguran. Karena hal ini sesuai dengan isi dari Undang-Undang 1945 yang berbunyi bahwa Tiap-tiap warga negara berhak atas pekerjaan dan penghidupan yang layak, maka pemerintah wajib menyediakan lapangan kerja dan melindungi hak-hak tenaga kerja. Dengan bunyi pada UndangUndang 1945 tersebut membuat pemerintah di Indonesia mau berusaha dengan keras memberikan peluang-peluang usaha dan menyediakan Balai Latihan Kerja untuk pendudduk Indonesia yang sudah berusia produktif.

Pemerintah Indonesia telah menciptakan lapangan kerja yang luas untuk masyarakat yang menjadi pengangguran. Kemudian pemerintah Indonesia membuka berbagai macam lembaga pelatihan kerja untuk warga negaranya. Hal ini dikarenakan pemerintah Indonesia ingin mengasah dan melatih para tenaga kerja sesuai dengan bidangnya masing-masing, dan hal ini juga penting untuk para tenaga kerja yang lebih memilih menjadi TKI atau TKW mereka diwajibkan memiliki suatu keahlian tertentu.

Masalah utama mengapa Indonesia memiliki tingkat pengangguran yang tinggi yaitu dikarenakan kebanyakan masyarakatnya menggantungkan nasib pada pekerjaan yang disediakan oleh pemerintah. Jarang sekali warga Indonesia yang memiliki keinginan untuk menjadi seorang wirausaha. Padahal dari lembagalembaga latihan kerja tersebut bisa dijadikan pengalaman untuk membuka sebuah lapangan pekerjaan. Keuntungan dari menjadi seorang wirausaha yaitu bisa membantu pemerintah dalam mengurangi tingkat pengangguran karena dengan begitu akan banyak membutuhkan tenaga kerja yang dibutuhkan untuk pekerjaan tersebut. Dan padahal menjadi seorang wirausaha dapat memiliki penghasilan yang lebih besar dibandingkan ketika hanya menjadi pegawai disuatu pekerjaan.

Kebanyakan rakyat Indonesia tidak ingin menjadi wirausaha hal itu dikarenakan keterbatasan modal yang dimiliki untuk membuka sebuah usaha. Padahal pemerintah sendiri sudah memberi fasilitas bantuan modal melalui Kredit Usaha Mikro yang ada diBank yang banyak berdiri di Indonesia. Seharusnya masyarakat bisa menggunakan fasilitas-fasilitas dari pemerintah sebaik mungkin. 
Apabila masyarakat tidak mempunyai kesadaran bahwa menjadi wirausaha turut membantu pemerintah dalam menguragi pengangguran dan hanya terus bergantung pada lapangan kerja yang dibuka pemerintah saja. Maka sampai kapanpun masalah pengangguran ini tidak akan selesai. Tetapi tingkat kesadaran masyarakat akan fasilitas yang diberika oleh Bank-Bank ini juga bisa disebabkan oleh kurangnya sosialisasi dari pemerintah ataupun dari pihak Bank-Bank yang menyediakan bantuan modal melalui Kredit Usaha Mikro. Kebanyakan masyarakat beranggapan bahwa apabila meminjam modal dari Bank akan dikenai oleh bunga yang tinggi, padahal program Kredit Usaha Mikro yang dikeluarkan oleh Bank ini memiliki bunga yang sangat rendah dibandingkan kredit pada program lain.

Dari uraian diatas jelas sekali bahwa masalah utama yang terjadi di setiap negara adalah masalah kemiskinan dan pengangguran. Masalah kemiskinan dan pengangguran ini adalah masalah yang sangat berkaitan dan saling berurutan. Hal ini terjadi dimana negara tersebut dikatakan negara miskin dikarenakan warga negara tersebut banyak yang menganggur. Dan demikian juga sebaliknya, negara tersebut dikatakan memiliki tingkat pengangguran yang tinggi dikarenakan rakyatnya yang miskin akibat tidak mendapatkan bantuan modal untuk membuka usaha dari pemerintah negara, dan kurang atau ketidaksadaran masyarakat tentang keuntungan membuka lapangan pekerjaan sendiri.

Masalah lain yang juga menjadi serangkaian dengan kemiskinan dan pengangguran adalah masalah dari kualitas Sumber Daya Manusianya yang rendah. Sumber daya manusia yang rendah mengakibatkan pengangguran dan kemiskinan hal ini dikarenakan masyarakat yang memiliki sumber daya manusia yang rendah tersebut tidak memiliki atau tidak mampu mengasah kemampuan dalam diri. Dan mereka kurang bersosialisasi tentang pentingnya lembaga pelatihan kerja yang dibuka dari pemerintah negaranya. Tingkat sumber daya manusia yang baik maka akan ikut memajukan negara. Hal ini memerlukan perhatian yang khusus dari pemerintah supaya memajukan pendidikan baik pendidikan formal maupun pendidikan informal seperti lembaga kursus. Dan diharapkan kepada masyarakat juga supaya dapat mengasah atau menemukan kemampuan yang ada dalam diri masing-masing.

Seperti halnya dinegara kita, di Indonesia sendiri banyak sekali berdiri lembaga-lembaga pelatihan kerja yang didikiran oleh pemerintah. Tapi lembaga 
tersebut kurang di manfaatkan oleh masyarakat Indonesia. Banyak sekali masyarakat yang menggantungkan nasib nya pada pekerjaan yang dibuka atau disediakan oleh pemerintah. Ciri khas dari bangsa Indonesia adalah lebih suka menjadi karyawan negara dibandingkan menjadi pemilik usaha. Padahal ketika satu orang berani membuka satu lapangan kerja saja itu sudah banyak membantu pemerintah untuk mengurangi banyaknya pengangguran. Dari mengikuti lembaga-lembaga pelatihan kerja ini diharapkan bahwa masyarakat dapat mengetahui atau mengasah potensi dalam diri sehingga ketika membuka lapangan kerja tersebut sesuai dengan potensi yang dimiliki masing-masing orang.

Masalah lainnya ketika membicarakan soal membuka lapangan pekerjaan, pertama kali tentu yang ada dipikiran kita adalah ketersediaan modal. Di pemerintahan zaman sekarang untuk mendapatkan modal usaha bisa dibilang sangatlah mudah. Karena pemerintah sudah memfasilitasi dengan menyediakan bantuan dana yang biasa disebut dengan Kredit Usaha Mikro. Fasilitas pemerintah tersebut harusnya kita pergunakan dengan sebaik mungkin untuk modal membuka lapangan kerja baru. Bantuan modal yang difasilitasi oleh pemerintah tersebut memiliki bunga yang sangat terjangkau sekali untuk orang-orang yang ingin membuka usaha atau untuk mengembangkan usahanya.

Apabila pemerintah Indonesia mampu menggalakan para pengangguran untuk bergabung dalam lembaga-lembaga pelatihan kerja yang telah disediakan untuk memberikan pegalaman dan untuk mengasah kemampuan tiap pengangguran,maka sedikit demi sedikit tingkat pengangguran di Indonesia akan berkurang bahkan negara Indonesia bisa keluar dari survey pengangguran tertinggi didunia. Dan tentu saja secara otomatis hal tersebut akan mampu menyelamatkan masyarakat Indonesia dari belenggu kemiskinan. Tetapi melihat keadaannya yang terjadi sekarang ini pemerintah Indonesia belum mampu menggalakkan masyarakat Indonesia untuk bergabung dalam lembaga pelatihan kerja. Sehingga tingkat kemiskinan dan pengangguran di Indonesia masih saja tinggi. Masih banyak sekali masyarakat Indonesia yang enggan untuk membuka lapangan kerja. Hal tersebut karena kurangnya kesadaran diri, kurangnya keinginan dan juga kurangnya sosialisasi dari pemerintah tentang keuntungan menjadi wirausaha. Padahal sudah jelas bahwa beberapa orang yang memilih menjadi wirausaha ternyata lebih sukses 
disbanding mereka yang bekerja menjadi karyawan negara tetapi hal tersebut masih belum mampu membuka mata masyarakat Indonesia.

Bicara tentang pengangguran dan kemiskinan pada lingkup yang lebih kecil, di Kabupaten Tulungagung Jawa Timur misalnya. Di Kabupaten Tulungagung masih banyak sekali masyarakatnya yang berada digolongan menengah kebawah. Padahal di Kabupaten Tulungagung sendiri banyak sekali tersedia lapangan pekerjaan seperti contoh usaha konveksi. Beberapa tempat di Kabupaten Tulungagung banyak yang menjadi sektor usaha konveksi sehingga masyarakat sekitar menggantungkan hidupnya pada usaha tersebut. Ada pula remaja yang masih usia sekolah yang bekerja diusaha tersebut setiap pulang sekolah. Hal ini dilakukan karena tingkat kemiskinan yang ada di Kabupaten Tulungagung masih lumayan tinggi. Dan tidak sedikit remaja di Kabupaten Tulungagung tidak bisa melanjutkan pendidikannya karena harus ikut bekerja untuk membantu perekonomian dikeluarganya. Padahal apabila pendidikannya dijaga maka tidak menutup kemungkinan remaja putus sekolah tersebut bisa mengangkat derajat keluarga atau bisa menekuni Lembaga Pelatihan Kerja supaya bisa menjadi wirausaha.

Karena tingkat kemiskinan di Kabupaten Tulungagung cukup tinggi tersebut, maka beberapa masyarakat Kabupaten Tulungagung yang memiliki tingkat perekonomian yang lebih mampu tergugah hatinya untuk membantu sesama. Sehingga mereka mendirikan sebuah komunitas sosial yang diberi nama Komunitas Berbagi Nasi. Komunitas ini dibentuk atas dasar keinginan untuk membantu pemerintah Kabupaten Tulungagung untuk meringankan beban warga sekitar yang mengalami kekurangan dari segi ekonomi. Hal ini juga bisa sekaligus menunjukan kepada pemerintah Kabupaten Tulungagung bahwa masih ada banyak sekali warga nya yang memiliki tingkat perekonoman yang rendah.

\section{TINJAUAN PUSTAKA}

Hall dan Midgley (2004:14) kemiskinan adalah kondisi deprivasi materi dan sosial yang menyebabkan individu hidup dibawah standar kehidupan yang layak atau kondisi dimana individu mengalami deprivasi relative dibandingkan dengan individu yang lain didalam masyarakat.

Nanga (2005:249) pengangguran adalah suatu keadaan dimana seseorang yang tergolong dalam ketegori angkatan kerja tidak memiliki pekerjaan dan secara 
aktif tidak sedang mencari pekerjaan. Dalam sensus penduduk 2001 mendefinisikan pengangguran sebagai orang yang tidak bekerja sama sekali atau bekerja kurang dari dua hari dalam seminggu sebelum pencacahan dan berusaha memperoleh pekerjaan.

Kertajaya Hermawan (2008) komunitas adalah sekelompok orang yang saling peduli satu sama lain lebih dari yang seharusnya, dimana dalam sebuah komunitas terjadi relasi pribadi yang erat antar para anggota komunitas tersebut karena adanya kesamaan interest atau values.

Poloma (2004:301) Kontruksi sosial adalah proses sosial melalui tindakan dan interaksi dimana individu menciptakan secara terus menerus suatu realitas yang dimiliki dan dialami bersama secara subyektif.

Soerdjono Soekanto (2006:104) Komunitas sosial adalah himpunan atau kesatuan manusia yang hidup bersama, karena adanya hubungan diantara mereka. Hubunga tersebut antara lain menyangkut hubungan timbal balik yang saling mempengaruhi dan juga suatu kesadaran untuk saling menolong.

\section{METODE PENELITIAN}

Penelitian ini menggunakan jenis metode penelitian kualitatif. Kualitatif adalah pengertian yang bermaksud memahami fenomena tentang apa yang dialami subjek penelitian misalnya perilaku, persepsi, motivasi, tindakan, dll secara holistik dan dengan cara deskripsi dalam bentuk kata-kata dan bahasa, pada suatu konteks khusus yang alamiah dan dengan memanfaatkan berbagai metode alamiah menurut Moleong(2007:6). Metode ini menghasilkan data deskriptif berupa kata-kata tertulis atau lisan dari orang-orang dan perilaku yang di amati. Informan yang dipilih untuk pembuatan penelitian ini adalah Farid Andy, Indiana, Karuniati dan Karuniatin.

\section{PEMBAHASAN}

Komunitas adalah kelompok sosial yang memiliki tujuan yang sama. Komunitas sosial adalah kelompok sosial atau orang-orang yang memiliki tujuan untuk mensejahterakan sesama. Salah satu komunitas sosial adalah Komunitas Berbagi Nasi. Komunitas ini adalah komunitas sosial dikarenakan tujuan utamanya yang membantu kaum dhuafa untuk sedikit meringankan beban mereka. Khususnya 
warga jalanan di Kabupaten Tulungagung misalnya tukang becak, pengamen dan pengemis.

Komunitas Berbagi Nasi adalah komunitas yang didirikan oleh sekumpulan masyarakat yang lebih mampu dalam segi ekonomi dengan tujuan untuk mensejahterakan masyarakat kurang mampu yang berada di Kabupaten Tulungagung. Komunitas Berbagi Nasi berdiri pertama kali di Bandung pada tahun 2012. Sedangkan untuk regional Tulungagung berdiri pada 2013 tetapi pada tahun 2014 Komunitas Berbagi Nasi sempat vakum karena sebagian besar anggota nya banyak yang bekerja dan sudah berkeluarga sehingga pada kegiatanya tidak bisa maksimal. Kemudian ditahun 2015 salah seorang anggota yang bernama Indiana mencoba mengaktifkan kembali Komunitas ini dibantu oleh Komunitas Berbagi Nasi dari Kediri dan Blitar. Sehingga sampai sekarang ini Komunitas Berbagi Nasi bisa berjalan dengan baik. Awal mula berdirinya, Komunitas ini menyalurkan donasi berupa nasi dan air yang dibawa oleh masing-masing anggota seikhlasnya. Tetapi karena Komunitas ini semakin maju dan dikenal banyak masyarakat Kabupaten Tulungagung sehingga sudah ada donator tetap yang akan mendonasikan nasi dan air ini kecuali dari anggota komunitas. Sehingga tugas dari anggota Komunitas Berbagi Nasi semakin ringan yaitu hanya membagi-bagikan donasi kepada kaum dhuafa. Komunitas ini sengaja tidak memilih ketua komunitas. Karena dikhawatirkan akan terjadi penguasaan komunitas. Sehingga semua keputusan untuk kemajuan komunitas ini dipilih langsung sesuai dengan saran-saran dari anggota yang ditampung.

Karena tujuan didirikannya komunitas ini adalah untuk membantu mensejahterakan kaum dhuafa di Kabupaten Tulungagung. Salah satu cara komunitas ini membantu mensejahterakan kaum dhuafa adalah dengan cara membagikan bungkusan nasi dan air minum kepada kaum dhuafa seperti tukang becak, pengemis dan pengamen. Kegiatan tersebut merupakan kegiatan rutin yang dilakukan oleh komunitas ini setiap seminggu sekali pada hari Jumat malam dimulai pada pukul 21.00 WIB. Sebelum kegiatan ini dimulai para anggota Komunitas berkumpul di depan kantor Bupati Kabupaten Tulungagung. Tujuan Komunitas ini berkumpul adalah untuk menerima bantuan nasi dari masyarakat sekitar. Setelah persiapan selesai, barulah anggota-anggota Komunitas Berbagi Nasi tersebut menyebar ke tempat-tempat dimana banyak kaum dhuafa, seperti di Terminal, 
Stasiun, Pasar, dan didepan toko-toko yang sudah tutup. Komunitas Berbagi Nasi sengaja memulai kegiatan rutin nya dimalam hari karena lebih mudah untuk menemukan kaum dhuafa.

Sesuai yang diungkapkan oleh salah satu anggota :

sengaja kegiatannya dijalankan malem supaya mudah menemui kaum dhuafa. Karena merekakan biasa istirahat didepan toko-toko yang sudah tutup. Kalau waktu siang kan sulit ketemu sama orang yang benar-benar dalam kondisi membutuhkan bantuan kita

Selain kegiatan rutin membagikan nasi yang dilaksanakan seminggu satu kali, Komunitas Berbagi Nasi juga melakukan kegiatan sosial lainnya seperti mengunjungi rumah penderita disabilitas yang sekaligus berada pada keluarga yang tidak mampu, mengadakan acara Gebyar Konser Amal, buka bersama dengan anak yatim, berbagi ta'jil dan juga memberikan bantuan kepada masyarakat korban bencana alam. Komunitas Berbagi Nasi dalam melaksanakan kegiatannya seringkali bekerja sama dengan komunitas sosial lainnya, seperti misalnya dengan Komunitas Ketimbang Ngemis. Komunitas Ketimbang Ngemis ini pun juga sudah tersebar diberbagai kotakota diIndonesia. Komunitas Berbagi Nasi bekerja sama dengan Komunitas Ketimbang ngemis dikarenakan memiliki visi dan misi yang sama. Yaitu sama-sama membantu mensejahterakan kehidupan dari kaum Dhuafa.

Kegiatan mengunjungi rumah penderita disabilitas dilaksanakan paling cepat sebulan sekali. Komunitas Berbagi Nasi mengunjungi rumah penderita disabilitas dengan membawa bantuan dari hasil menggalang bantuan berupa uang dan sembako. Pada awal berdirinya, komunitas ini sudah membantu balita usia 8 bulan asal Sendang Kabupaten Tulungagung yang menderita leukemia, ispa, kelainan jantung dan gizi buruk, selain balita tersebut Komunitas Berbagi Nasi juga biasa mengunjungi rumah kaum dhuafa yang sudah berusia lanjut dan memiliki rumah yang sudah jauh dari kata layak, hal ini Komunitas Berbagi Nasi berharap supaya pemerintah mau memberikan bantuan untuk memperbaiki tempat tinggal bagi warga atau kaum dhuafa yang sudah lanjut usia yang sudah tidak layak untuk dihuni. Sering kali Komunitas Berbagi Nasi menjumpai rumah-rumah kaum dhuafa usia lanjut yang atapnya sudah tidak kuat untuk menyangga genteng.

Kegiatan Gebyar Konser Amal ini berjalan dengan cara para anggota atau para pejuang nasi ini melakukan penggalangan dana diberbagai tempat dan juga dengan cara mendirikan sebuah event sosial dengan menampilkan para seniman-seniman di Kabupaten Tulungagung. Baru-baru ini organisasi berbagi nasi menggalang dana 
untuk membantu seorang anak dan bapak yang sedang sakit. Yaitu Dek Anisa, siswi kelas 4 SD ini menderita tumor syaraf dan sang ayahanda yang menderita Diabetes sehingga mengalami gangguan penglihatan. Ayah dan anak ini sangat memerlukan bantuan dana untuk berobat ke Rumah Sakit. Salah satu anggota Komunitas Berbagi Nasi juga mengutarakan :

komunitas ini emang ikut serta dalam kegiatan sosial seperti Gebyar Konser Amal. Tujuannya ya biar kita mudah untuk saling berbagi. Biar orang yang butuh bantuan kita juga dapat sorotan dari komunitas sosial yang juga sejenis sama Komunitas Berbagi Nasi ini sehingga kan bisa menambah bantuan yang diterima oleh yang butuhin. Banyak kok sebab dari mereka kenapa bisa mengalami kekurangan. Misalnya karena sakit terus ga bisa kerja. Ada juga yang sebenernya udah kerja tapi penghasilnnya cuma berapa rupiah, ngga cukup lah antara pengeluaran dan pemasukannya padahal salah satu anggota keluarganya ada yang sakit keras, rata-rata ya kena kanker juga kena stroke dan jantung. Padahala kan itu butuh biaya pengobatan yang banyak ya

Selain melakukan kegiatan membagikan nasi dan membuat acara Gebyar

Konser Amal, Komunitas Sosial Berbagi Nasi juga membantu sesama apabila sedang ada saudara yang terkena musibah. Seperti contohnya membantu korban tanah longsor di Desa Banaran Kabupaten Ponorogo. Seperti yang kita ketahui bahwa bencana ini termasuk dalam bencana yang lumayan besar karena merenggut banyak nyawa dan mengubur rumah - rumah para warga. Komunitas Berbagi Nasi Tulungagung menggalang donasi berupa bantuan dana atau berupa barang yang masih layak pakai untuk diberikan kepada para korban tanah longsor di Desa Banaran Kabupaten Ponorogo. Komunitas Berbagi Nasi bekerja sama dengan Komunitas Penerima Beasiswa Bank Indonesia (GenBI) dari IAIN Tulungagung. Donasi tersebut kemudian disalurkan oleh GenBI Jawa Timur untuk diberikan kepada para korban tanah longsor.

Kegiatan yang dilakukan Komunitas ini tidak hanya itu. Tetapi disaat bulan puasa tiba ada agenda wajib Komunitas Berbagi Nasi yaitu berbagi ta'jil, sahur on the road dan buka bersama anak yatim. Anggota - anggota organisasi ini berkumpul beberapa jam sebelum kegiatan membagikan ta'jil digerakkan. Ta'jil mereka bawa dari rumah untuk dibagi-bagikan. Sasaran anggota bernas membagikan ta'jil yaitu dilampu-lampu merah sekitar pusat Kabupaten Tulungagung. Tujuan organisasi ini membagi-bagikan ta'jil selain untuk bersedekah juga untuk mengenalkan kesebagian besar warga Kabupaten Tulungagung bahwa di Kabupaten Tulungagung ada organisasi sosial Berbagi Nasi. Dengan begini organisasi Berbagi Nasi bisa semakin dikenal oleh masyarakat dan akan banyak yang berminat untuk bergabung menjadi 
anggota. Untuk sahur on the road sendiri anggota komunitas embagikan nasi dan air ketika jam masuk sahur dan para angggota komunitas juga sekalian sahur dipinggirpinggir jalan. Dan untuk buka bersama anak yatim ini tidak satu bulan penuh dilaksanakan, tetapi hanya maksimal dua kali dilaksanakan tiap bulan puasa.

Tidak hanya di Kabupaten Tulungagung saja, ternyata Komunitas Berbagi Nasi sudah tersebar dibeberapa daerah di Indonesia. DiJawa Timur saja sudah lebih dari 5 kota atau kabupaten yang memiliki organisasi ini. Seperti misalnya Kota Blitar, Kota Kediri, dan lain lain. Di daerah-daerah yang lain Komunitas Berbagi Nasi juga berjalan dengan lancar. Setiap beberapa bulan sekali organisasi berbagi nasi dari tiap-tiap daerah di Jawa Timur ini mengadakan pertemuan guna untuk menjalin silatuhrahmi antar komunitas sosial berbagi nasi daerahnya. Biasanya Komunitas ini bertemu seperti dalam kegiatan berbagi nasi dimalam hari. Komunitas Berbagi Nasi Kabupaten Tulungagung biasanya bergabung dengan organisasi berbagi nasi dari Kota Blitar dan juga dari Kota Kediri. Selain dengan kegiatan tersebut, organisasi daerah biasanya akan diundang apabila salah satu Komunitas Berbagi Nasi daerah sedang mengadakan acara-acara sosial seperti event Gebyar Konser Amal. Ini supaya donasi yang didapat untuk disumbangkan bisa mendapat lebih banyak lagi. Kerjasama antar Komunitas Berbagi Nasi tiap daerah seperti ini juga baik untuk organisasi ini supaya bisa saling memperbaiki kekurangan yang ada supaya dalam kegiatan mereka membantu kaum dhuafa bisa terlaksana dengan baik dan merata.

\section{PENUTUP}

\section{Kesimpulan}

Kemiskinan dan pengangguran adalah hantu yang paling ditakuti di tiap tiap negara. Kemiskinan dan pengangguran seperti ibarat sebuah pasangan yang tidak dapat dipisahkan, dan saling berkesinambungan. Karena dimana tingkat pengangguran disebuah negara tinggi pasti kemiskinan dinegara tersebut juga tinggi, dan sebaliknya apabila tingkat kemiskinan tinggi berarti tingkat pengangguran juga tinggi. Tetapi ketika dalam sebuah negara memiliki tingkat kemiskinan yang rendah hal itu dapat dipastikan bahwa negara tersebut memiliki penduduk dengan jumlah pengangguran yang rendah, dan sebaliknya tingkat pengangguran yang rendah akan mengasilkan tingkat kemiskinan penduduk yang rendah pula. Apalagi pasangan ini 
sangat ramah keberadannya untuk negara berkembang. Sehingga banyak sekali negara yang ingin keluar dari bencana kemiskinan dan pengangguran. Salah satu cara untuk keluar dari belenggu ini adalah dengan memberikan lapangan pekerjaan, menyediakan bantuan modal untuk penduduk yang ingin membuka usaha dan membuka balai pelatihan kerja untuk warganya. Dan kritik untuk pemerintah setempat pun seharusnya menggalakkan pemberdayaan untuk kaum dhuafa. Pemberdayaan kaum dhuafa sangatlah penting karena dengan begini maka kaum dhuafa yang memerlukan bantuan bisa merasa ringan beban nya karena bantuan dari organisasi sosial atau relawan-relawan. Memang sudah banyak bantuan dari pemerintah untuk kaum dhuafa seperti kartu kartu yang digunakan untuk meringankan beban misalnya dalam kesehatan. Tetapi pada berjalannya waktu, perbedaan pelayanan untuk penduduk yang mengandalkan kartu bantuan kesehatan ini sangat banyak menimbulkan keluhan dari kaum dhuafa. Hal ini seharusnya diperhatikan oleh pemerintah daerah supaya dalam kerjanya, organisasi sosial bisa dengan sempurna karena dapat bantuan dari pemerintah daerah. Organisasiorganisasi sosial ini sebenarnya membantu meringankan pekerjaan pemerintah. Sehingga lebih baik apabila pemerintah juga melakukan timbal balik terhadap organisasi-organisasi sosial.

\section{DAFTAR PUSTAKA}

Hall, A \& Midgley, J. 2004. Social Policy for Development, London: Sage Publication.

Muana, Nanga. 2001. Makro ekonomi, Teori, Masalah dan Kebijakan. Edisi Perdana. PT Raja Grafindo Perkasa: Jakarta.

Undang- Undang 1945.

Kertajaya, Hermawan. 2008. Arti Komunitas, Gramedia Pustaka Utama.

Soekanto, Soerdjono. 2006. Sosiologi Suatu Pengantar, PT. Raja Grafindo Persada: Jakarta.

Poloma, M. Margaret. 1994. Sosiologi Kontemporer. Rajawali Grafindo Persada: Jakarta.

Poloma, M. Margaret. 2000. Sosiologi Kontemporer. CV. Rajawali: Jakarta.

Moleong, Lexy. 2007. Metode Penelitian Kualitatif, Remaja Rosda Karya: Bandung. Wikipedia.org 